\section{Peanut Protein: Rich Source as Vegan Protein}

\section{Jani $\mathrm{BL}^{*}$ and Devani BM}

Department of Processing and Food Engineering, College of Agricultural Engineering and Technology, Junagadh Agricultural University, Junagadh, Gujarat, India

\begin{abstract}
Protein is a building block and contributor for growth and development and different activities in human body system. Various animal and plant based food are rich source of protein and essential amino acids. Egg protein, milk protein, soy protein, peanut protein and many proteins contain essential amino acids having various health benefits and functional properties. Peanut is an important oilseed and defatted peanut flour is a byproduct of peanut oil milling industry with a rich source of protein. This protein can be concentrated as Peanut Protein Concentrate (PPC) and Peanut Protein Isolate (PPI) with around $80-85 \%$ and more than $90 \%$ protein, respectively. Peanut protein can be extracted for bioactive peptides, hydrolysates, can also be converted into texturized protein such as meat analogue, packaging film. Favorable functional properties of peanut protein such as emulsifying activity, emulsifying stability, foaming capacity, excellent water retention and high solubility etc. made it versatile for various food system. Various extraction methods such as isoelectric precipitation, aqueous precipitation, isoelectric precipitation, alcohol precipitation, Ultrafiltration (UF) and combination of thereof are used for preparation of PPC and PPI. The peanut protein can compete with another animal and plant proteins with all the required health benefits and functional properties necessary for the food system. There is a huge scope in exploring peanut protein as source of vegan protein.
\end{abstract}

Keywords: Functional properties; Peanut protein; Vegan protein

\section{Introduction}

Nature has classified food as source of energy in various ways according to the need of our body. Different food plays important role

\footnotetext{
*Corresponding author: Bhavesh $\mathrm{L}$ Jani, Department of Processing and Food Engineering, College of Agricultural Engineering and Technology, Junagadh Agricultural University, Junagadh, Gujarat, India, Tel: +91 8141800508; E-mail: jb9_bhavesh@yahoo.com
}

Citation: Jani BL, Devani BM (2020) Peanut Protein: Rich Source as Vegan Protein. J Food Sci Nutr 6: 059.

Received: February 15, 2020; Accepted: March 16, 2020; Published: March 25,2020

Copyright: (C) 2020 Jani BL, et al. This is an open-access article distributed under the terms of the Creative Commons Attribution License, which permits unrestricted use, distribution, and reproduction in any medium, provided the original author and source are credited. in the energy requisites of our body such as physical activity, metabolic process, growth and development and many important activities. Protein and the amino acids are the building blocks of life. They play a critical role as components of blood, muscle, enzymes, hormones and hormone receptors. In addition to this protein also imparts taste, texture and flavor to the food which are very important factors in selecting foods.

In nature, proteins exist as components of biological matrices with other compounds such as lipids, carbohydrates, minerals and other minor components. The vegetable sources of protein concentrate or isolate contain protein in the range of 30 to $50 \%$ while the protein in concentrate and isolate comprise of $60-80$ and $>90 \%$ protein, respectively depending up on the process technology of extraction of protein adopted. For protein extraction, different techniques have been developed among them micellization, ultrafiltration, acidic and alkaline aqueous extraction followed by isoelectric precipitation. On the other hand, protein sources have been added in food elaboration/production due to its physicochemical properties like water and oil absorption capacities, gelification and foaming and emulsifying properties, which affects food protein behavior and influence in quality and organoleptic characteristics from food system. Protein concentrates and isolates from the flour of different foods have been obtained, which decrease the non-protein components in order to obtain a final product with high protein content.

Peanut, an important oil and food crop is currently grown on approximately 42 million acres worldwide. India, China and the United States have been the leading producers for over 25 years and grow about $70 \%$ of the world crop. With annual all-season coverage of about 70 lakh hectares, globally India ranks first in groundnut acreage and with an output of approx. 80-85 lakh MT (in shell groundnuts), second in production. Although in various states of India groundnut is cultivated in one or more (kharif, rabi and summer) seasons, nearly $80 \%$ of acreage and production comes from kharif crop (June-October). Among the many commercial uses of peanuts, extraction of oil from peanut yields Defatted Peanut Flour (DPF). DPF is an underutilized by-product of peanut processing that has been used for extending comminuted meat products, production of beverages, fermented products, composite flours and protein supplementation of bakery products and weaning foods. Despite the fact that DPF has an excellent potential in food formulations because of the high protein content, its uses remain limited.

In recent years, the need for less expensive proteins and the growing demand for alternatives to meat have increased interest in the potential of peanut by-products as a source of edible vegetable protein such as DPF. As like high protein soya flour, the DPF can be processed to yield meat-like products that can be used to formulate cholesterol-free vegetarian alternatives to many of the traditional meat-based food products. One way of producing meat-like products from DPF is extrusion cooking to texturize peanut proteins into fibrous meat substitutes. Despite the increased use of extrusion processing, extrusion is still a complex process that has to be optimized for specific applications based on the nature of raw materials and desired final product. 
Even within a given extrusion process, small variations in processing conditions affect process variables as well as product quality. Product quality can vary considerably depending on process variables such as the extruder type, screw configuration, feed moisture and temperature profile in the barrel, screw-speed and feed rate and die profile [1].

The peanut proteins had good emulsifying activity, emulsifying stability, foaming capacity, excellent water retention and high solubility and would also provide a new high protein food ingredient for product formulation and protein fortification in food industry [2]. Therefore, the peanut proteins can be regarded as one of the most attractive and promising vegetable proteins. Adequate modification on proteins may improve their functional properties, so detailed investigation of peanut proteins is necessary to elucidate the functional properties of peanut proteins. Similar process was also found to enhance the solubility and other functional properties of peanut proteins. Yu et al. [3], reported that the peanut flour by fermented treatment and Peanut Protein Concentrate (PPC) could enhance the functional properties of peanut proteins and peanut flour. Functional properties of many other plant protein concentrates/isolates produced from peas and beans were also studied by a number of investigators [4]. Functional properties of peanut protein have been the subject of limited studies $[2,3]$. Among plant proteins, the nutritional value of peanut proteins is lower than soy proteins, but the anti-nutritional factor content of peanut proteins is less than that of soy proteins. So it is important to study the functional properties of protein concentrates/ isolates.

Other than contribution from proteins, peanut meals likely possess few other compounds in significant quantities that will impact functionality of peanut proteins, such as polysaccharides. Polysaccharides in manufactured products can improve structure and stability, but it will reduce in vivo and vitro protein digestibility and nutrient absorption. The decrease of protein digestibility by polysaccharides is often explained by the interactions between these two macromolecules that prevent the protein hydrolysis [5]. But little information is available on peanut polysaccharides that actually contribute to total functional properties. The methods of conventional industrial processing peanut oil involve crushing and solvent extraction. Thus, very little attention is given to the protein residue. Due to the denaturizing of protein or residual solvent, the protein residue is mainly used in the manufacture of compound feed stuffs or fertilizer. Although it has been recognized that the peanut protein resource is one of important plant proteins, it cannot be utilized reasonably. Recently, many researchers focus on exploring new technologies to separate peanut proteins and oil.

Traditionally, the separation of peanut proteins had been done by isoelectric precipitation, alcohol precipitation, isoelectric precipitation with alcohol precipitation, hot water extraction and alkali solution with isoelectric precipitation [3]. However, the methods have some fatal defects. For example, a great deal of wastewater produced causes serious environmental pollution and it is also limited capacity of raw material treatment and high consumption of acid and alkali. Moreover, it is easy to cause protein denaturation. Therefore, it is necessary to explore an alternative extraction approach of peanut proteins.

\section{Peanut protein concentration and isolates}

Most peanuts grown in the US are used for oil production, peanut butter, confections and snack products. Vegetable oil extraction from peanut yields partially Defatted Peanut Flour (DPF). DPF is a protein-rich, inexpensive and underutilized by-product of the peanut industry that offers the same health and dietary benefits of peanut with less fat. DPF contains $47-55 \%$ high quality protein with high essential amino acid content [6] and lends itself being used in many food applications. The development of a Peanut Protein Concentrate (PPC) from defatted peanut flour would also provide the food industry with a new high protein food ingredient for product formulation and protein fortification. The latter is critically needed in many developing countries where protein deficiencies remain a major health problem, especially among children (Table 1).

\begin{tabular}{|c|c|c|c|}
\hline Preparing Sample & Method & Features & References \\
\hline \multirow{6}{*}{$\begin{array}{l}\text { Peanut protein } \\
\text { concentrates }\end{array}$} & Isoelectric precipitation & $\begin{array}{l}\text { Better functional properties, worse color and flavor, lower extraction efficiency, } \\
\text { severe contamination for environment }\end{array}$ & $\begin{array}{l}\text { Liu et al. [7] } \\
\text { Yu et al. [3] } \\
\text { Wu et al. [2] }\end{array}$ \\
\hline & Aqueous precipitation & Poor functional properties, protein denaturation, lower extraction efficiency & $\begin{array}{l}\text { Yu et al. [3] } \\
\text { Wu et al. [2] }\end{array}$ \\
\hline & Alcohol precipitation & Better color and flavor, poor functional properties, lower nitrogen solubility index & $\begin{array}{l}\text { Yu et al. [3] } \\
\text { Wu et al. [2] }\end{array}$ \\
\hline & $\begin{array}{l}\text { Isoelectric precipitation and alcohol } \\
\text { precipitation }\end{array}$ & Better color and flavor, poor functional properties, lower nitrogen solubility index & $\begin{array}{l}\text { Yu et al. [3] } \\
\text { Wu et al. [2] }\end{array}$ \\
\hline & Hexane and aqueous alcohol precipitation & $\begin{array}{l}\text { Better functional properties, higher nitrogen solubility index, lower coefficient of } \\
\text { solvents recovery }\end{array}$ & Yu et al. [3] \\
\hline & Ultrafiltration (UF) & $\begin{array}{l}\text { no need for any chemicals, higher yield and superior functional properties of the } \\
\text { UF protein product non-thermal and non-chemical nature of the UF process, mem- } \\
\text { brane easily contaminated and be difficult to clean }\end{array}$ & Krishna Kumar et al. [8] \\
\hline \multirow{2}{*}{ Peanut protein isolates } & $\begin{array}{l}\text { Alkali solution and isoelectric precip- } \\
\text { itation }\end{array}$ & $\begin{array}{l}\text { Better functional properties, higher extraction efficiency, severe contamination for } \\
\text { environment }\end{array}$ & $\begin{array}{l}\text { Dumay et al. [9]; } \\
\text { Yu et al. [3]; } \\
\text { Wu et al. [2] }\end{array}$ \\
\hline & Ultrafiltration (UF) & $\begin{array}{l}\text { No need for any chemicals, higher yield and superior functional properties of } \\
\text { the UF protein product non-thermal and non-chemical nature of the UF process, } \\
\text { membrane easily contaminated and be difficult to clean }\end{array}$ & Krishna Kumar et al. [8] \\
\hline
\end{tabular}

Table 1: Different methods for obtaining the peanut protein concentrate and isolates. 


\section{Importance of different functional properties of PPC and PPI}

Functional properties of food proteins are important in food processing and food product formulation. Some of these properties are water/oil binding, emulsification, foam affected by the intrinsic factors of protein such as molecular structure and size and many environmental factors including the method of protein separation/production, $\mathrm{pH}$, ionic strength and the presence of other components in the food system. The importance of these properties varies with the type of food products in which the protein concentrate is used. For example, proteins with high oil and water binding are desirable for use in meats, sausages, breads and cakes, while proteins with high emulsifying and foaming capacity are good for salad dressing, sausages, bologna, soups, confectionery, frozen desserts and cakes [10]. Functional properties of protein are influenced by many factors. For end users, $\mathrm{pH}$, temperature and ionic strength of the food system are important factors to consider. For producers, methods and conditions of protein extraction, as well as downstream processing of extracted proteins such as purification and drying are the factors need to be addressed. Methods used to develop plant protein isolate/ concentrate include isoelectric precipitation, alcohol precipitation and hot water extraction.

Peanut protein can be considered from multiple quality perspectives, including seed physiology, seed agronomic performance, human and animal nutrition, flavor development during thermal processing, and peanut allergy, among others. In the case of nutrition, protein is a basic and critical input for human (food) and animal (feed) growth and vitality and the world's protein supplies are under extreme pressure considering our planet's exponentially increasing population. Plant proteins are inherently more efficient to produce than animal protein, and increased future emphasis is expected to be placed on producing more plant protein more efficiently, i.e., with less land, water and inputs, for food and feed. Among regularly consumed nuts (tree nuts and peanuts) worldwide, peanuts have the greatest protein content [11], which is commonly reported near $25.8 \%$. Peanut protein, as a primary component of defatted solids, has shown cardiovascular health-promoting effects in model studies [12].

\section{Amino acid composition}

Amino acids are the primary subunits of all proteins and the typical amino acid composition (relative \%) of peanut protein derived from either blanched peanut seed or removed peanut testae (skins) is provided in table 2 [13]. Amino acid data for blanched seed is ultimately most relevant to peanut nutrition as the skin only accounts for approximately $3 \%$ of the total seed weight after shelling and skins are relatively low in total protein compared with the blanched seed, i.e., approximately $15 \%$ versus $25 \%$. For blanched seed, asparagine/ aspartic acid and glutamine/glutamic acid residues predominate, accounting for approximately $35 \%$ of the amino acids, in good agreement with data from other sources $[11,14]$. Comparisons across common tree nuts and peanuts show that all are naturally high in these acidic amino acids, in addition to also being naturally high in hydrophobic amino acids, including leucine, glycine and valine, among others [11]. Peanut has a high percentage of arginine (12.5\%), which when coupled with its overall high protein content, makes peanut an important dietary source of this amino acid whose consumption has been directly linked to various cardiovascular health promoting activities.

\begin{tabular}{|c|c|c|c|}
\hline Amino Acid & $\begin{array}{c}\text { Defatted Peanut } \\
\text { Meal }\end{array}$ & $\begin{array}{c}\text { Peanut Protein } \\
\text { Concentrate }\end{array}$ & $\begin{array}{c}\text { Peanut Protein } \\
\text { Isolate }\end{array}$ \\
\hline Lysine & 3.0 & 3.0 & 3.0 \\
\hline Histidine & 2.3 & 2.4 & 2.4 \\
\hline Arginine & 11.3 & 12.6 & 12.8 \\
\hline Aspartic acid & 14.1 & 12.5 & 12.3 \\
\hline Threonine & 2.5 & 2.5 & 2.5 \\
\hline Serine & 4.9 & 5.2 & 5.1 \\
\hline Glutamic acid & 19.9 & 20.7 & 21.4 \\
\hline Proline & 4.4 & 4.6 & 4.8 \\
\hline Glycine & 5.6 & 4.2 & 4.1 \\
\hline Alanine & 4.2 & 4.0 & 1.4 \\
\hline Cystine & 1.3 & 1.4 & 4.4 \\
\hline Valine & 4.5 & 4.5 & 1.0 \\
\hline Methionine & 0.9 & 1.0 & 3.6 \\
\hline Isoleucine & 4.1 & 4.3 & 6.6 \\
\hline Leucine & 6.7 & 6.7 & 4.3 \\
\hline Tyrosine & 4.1 & 4.4 & 5.6 \\
\hline Phenylalanine & 5.2 & 5.2 & 1.0 \\
\hline Tryptophan & 1.0 & 1.1 & \\
\hline
\end{tabular}

Table 2: Amino acid compositions of peanut protein concentrate and Isolate $(\mathrm{g}$ $\left.\mathrm{AA} / 16 \mathrm{gN}_{2}\right)$.

Several measurements of protein nutritional quality based on amino acid composition are found in the scientific literature and these measures are typically a function of the target organism and its amino acid requirements, i.e., human or specific animal, amino acid composition of a given protein source, its digestibility and its subsequent bioavailability [14]. Considering human nutrition, there are $20 \mathrm{com}-$ mon amino acids, nine of which are essential, meaning the human body cannot synthesize these amino acids on its own given adequate calories. Peanut protein, like most vegetable proteins, is incomplete, meaning it is lacking adequate levels of at least one of the essential amino acids necessary for human nutrition. Based on controlled rat feeding studies, peanut is limiting in methionine, lysine and threonine [15]. Considering the recommended intakes of amino acid requirements of 2- to 5-year-old children, the first limiting amino acid in peanut is threonine [11]. While peanut is nutritionally deficient in certain essential amino acids, like most vegetable-based sources of protein, it is recognized that even in developing countries, protein sources are rarely isolated to one particular food and adequate essential amino acid intake is readily achieved by consuming complementary protein sources.

The peanut protein can be used for different food and feed purposes, also to make peanut protein biopeptides, hydrolysates, protein films etc. The peanut protein hydrolysates can be prepared by protein hydrolysis, acid hydrolysis, alkaline hydrolysis, enzymatic hydrolysis and microbial hydrolysis methods are used [16], while peanut protein films can be prepared by formation of peanut-protein-lipid films on the surface of heated peanut milk or by casting of PPC or PPI solutions. The film formation and different properties are greatly affected by $\mathrm{pH}$, drying temperature, plasticizer [17,18].

There is still wide scope of exploitation of knowledge as per requirement of industries. The protein isolates from peanuts have versatile applications as food ingredients and meat analogues and 
according to the industrial requirements; PPI can be modified and used for variety of applications.

\section{Summary}

Peanut protein has been so far considered as deficient source of amino acids while looking the compositions and importance, it is therefore necessary to enlighten the views and researches to make up peanut protein as a vegan diet source. Similar to other protein concentrates and isolates, protein from peanut has variety of applications in food and other industries as briefed in this article. Peanut protein is also a rich source of Arginine. Arginine or L-arginine is an amino acid that is needed to keep the liver, skin, joints and muscles healthy and is a precursor to nitric oxide that helps to keep the arteries relaxed, improving blood flow and healing time in tissues in the body. Commercialization of peanut protein as a vegan source is therefore having a demanding future, if worked out well.

\section{References}

1. Ding Q, Ainsworth P, Plunkett A, Tucker G, Marson H (2006) The effect of extrusion conditions on the functional and physical properties of wheatbased expanded snacks. Journal of Food Engineering 73: 142-148.

2. Wu H, Wang Q, Ma T, Ren J (2009) Comparative studies on the functional properties of various proteins concentrate preparations of peanut protein. Food Res Int 42: 343-348.

3. Yu J, Ahmedna M, Goktepe I (2007) Peanut protein concentrate: Production and functional properties as affected by processing. Food Chemistry 103: 121-129.

4. Lawal OS (2004) Functionality of African locust bean (Parkia biglobssa) protein isolate: Effects of $\mathrm{pH}$, ionic strength and various protein concentrations. Food Chem 86: 345-355.

5. Mouécoucou JS, Frémont C, Sanchez C, Villaume LM (2004) In vitro allergenicity of peanut after hydrolysis in the presence of polysaccharides. Clin Exp Allergy 34: 1429-1437.

6. Basha SM, Pancholy SK (1982) Composition and characteristics of basic proteins from peanut (Arachis hypogaea L.) seed. J Agric Food Chem 30 : $1176-1179$.
7. Liu DC, Zhang WN, Hu XH (2001) The research on preparation and functional properties of peanut protein. Journal of Wuhan Polytechnic University 10: 1-3.

8. Krishna Kumar NS, Yea MK, Cheryan M (2004) Ultrafiltration of soy protein concentrate: Performance and modeling of spiral and tubular polymeric modules. J Membrane Sci 244: 235-242.

9. Dumay E, Pieart L, Regnault S, Thiebaud M (2006) High pressure-low temperature processing of food proteins. Biochim Biophys Acta 1764: 599-618.

10. Ahmedna M, Prinyawiwatkul W, Rao RM (1999) Solubilised wheat protein isolate: Functional properties and potential food applications. J Agric Food Chem 47: 1340-1345.

11. Venkatachalam M, Sathe SK (2006) Chemical composition of selected edible nut seeds. Journal of Agricultural and Food Chemistry 54: 47054714.

12. Stephens AM, Dean LL, Davis JP, Osborne JA, Sanders TH (2010) Peanuts, peanut oil and fat free peanut flour reduced cardiovascular disease risk factors and the development of atherosclerosis in Syrian golden hamsters. J Food Sci 75: 116-122.

13. White BL, Goekce E, Nepomuceno AI, Muddiman DC, Sanders TH, et al. (2013) Comparative proteomic analysis and IgE binding properties of peanut seed and testa (skin). J Agric Food Chem 61: 3957-3968.

14. Guang C, Phillips RD, Shang J (2012) Functional and nutritional properties of peanut and cowpea proteins. J Food Agric Environ 10: 19-25.

15. Miller J, Young CT (1977) Protein nutritional quality of Florunner peanut meal as measured by rat bioassay. J Agric Food Chem 25: 653-657.

16. Pasupuleti VK, Steven B (2010) State of the art manufacturing of protein hydrolysates. Protein Hydrolysates in Biotechnology 11-32.

17. Bates RP, Wu LC (1975) Protein quality of soy protein-lipid films (yuba) and derived fractions. J Food Sci 40: 425-426.

18. Aboagye Y, Stanley DW (1985) Texturization of peanut proteins by surface film formation. 1. Influence of process parameters on film forming properties. Can Inst Food Sci Technol J 18: 12-20. 


\section{H}

Advances In Industrial Biotechnology | ISSN: 2639-5665

Advances In Microbiology Research | ISSN: 2689-694X

Archives Of Surgery And Surgical Education | ISSN: 2689-3126

Archives Of Urology

Archives Of Zoological Studies | ISSN: 2640-7779

Current Trends Medical And Biological Engineering

International Journal Of Case Reports And Therapeutic Studies | ISSN: 2689-310X

Journal Of Addiction \& Addictive Disorders | ISSN: 2578-7276

Journal Of Agronomy \& Agricultural Science | ISSN: 2689-8292

Journal Of AIDS Clinical Research \& STDs | ISSN: 2572-7370

Journal Of Alcoholism Drug Abuse \& Substance Dependence | ISSN: 2572-9594

Journal Of Allergy Disorders \& Therapy | ISSN: 2470-749X

Journal Of Alternative Complementary \& Integrative Medicine | ISSN: 2470-7562

Journal Of Alzheimers \& Neurodegenerative Diseases | ISSN: 2572-9608

Journal Of Anesthesia \& Clinical Care | ISSN: 2378-8879

Journal Of Angiology \& Vascular Surgery | ISSN: 2572-7397

Journal Of Animal Research \& Veterinary Science | ISSN: 2639-3751

Journal Of Aquaculture \& Fisheries | ISSN: 2576-5523

Journal Of Atmospheric \& Earth Sciences | ISSN: 2689-8780

Journal Of Biotech Research \& Biochemistry

Journal Of Brain \& Neuroscience Research

Journal Of Cancer Biology \& Treatment | ISSN: 2470-7546

Journal Of Cardiology Study \& Research | ISSN: 2640-768X

Journal Of Cell Biology \& Cell Metabolism | ISSN: 2381-1943

Journal Of Clinical Dermatology \& Therapy | ISSN: 2378-8771

Journal Of Clinical Immunology \& Immunotherapy | ISSN: 2378-8844

Journal Of Clinical Studies \& Medical Case Reports | ISSN: 2378-8801

Journal Of Community Medicine \& Public Health Care | ISSN: 2381-1978

Journal Of Cytology \& Tissue Biology | ISSN: 2378-9107

Journal Of Dairy Research \& Technology | ISSN: 2688-9315

Journal Of Dentistry Oral Health \& Cosmesis | ISSN: 2473-6783

Journal Of Diabetes \& Metabolic Disorders | ISSN: 2381-201X

Journal Of Emergency Medicine Trauma \& Surgical Care | ISSN: 2378-8798

Journal Of Environmental Science Current Research | ISSN: 2643-5020

Journal Of Food Science \& Nutrition | ISSN: 2470-1076

Journal Of Forensic Legal \& Investigative Sciences | ISSN: 2473-733X

Journal Of Gastroenterology \& Hepatology Research | ISSN: 2574-2566
Journal Of Genetics \& Genomic Sciences | ISSN: 2574-2485

Journal Of Gerontology \& Geriatric Medicine | ISSN: 2381-8662

Journal Of Hematology Blood Transfusion \& Disorders | ISSN: 2572-2999

Journal Of Hospice \& Palliative Medical Care

Journal Of Human Endocrinology | ISSN: 2572-9640

Journal Of Infectious \& Non Infectious Diseases | ISSN: 2381-8654

Journal Of Internal Medicine \& Primary Healthcare | ISSN: 2574-2493

Journal Of Light \& Laser Current Trends

Journal Of Medicine Study \& Research | ISSN: 2639-5657

Journal Of Modern Chemical Sciences

Journal Of Nanotechnology Nanomedicine \& Nanobiotechnology | ISSN: 2381-2044 Journal Of Neonatology \& Clinical Pediatrics | ISSN: 2378-878X

Journal Of Nephrology \& Renal Therapy | ISSN: 2473-7313

Journal Of Non Invasive Vascular Investigation | ISSN: 2572-7400

Journal Of Nuclear Medicine Radiology \& Radiation Therapy | ISSN: 2572-7419

Journal Of Obesity \& Weight Loss | ISSN: 2473-7372

Journal Of Ophthalmology \& Clinical Research | ISSN: 2378-8887

Journal Of Orthopedic Research \& Physiotherapy | ISSN: 2381-2052

Journal Of Otolaryngology Head \& Neck Surgery | ISSN: 2573-010X

Journal Of Pathology Clinical \& Medical Research

Journal Of Pharmacology Pharmaceutics \& Pharmacovigilance | ISSN: 2639-5649

Journal Of Physical Medicine Rehabilitation \& Disabilities | ISSN: 2381-8670

Journal Of Plant Science Current Research | ISSN: 2639-3743

Journal Of Practical \& Professional Nursing | ISSN: 2639-5681

Journal Of Protein Research \& Bioinformatics

Journal Of Psychiatry Depression \& Anxiety | ISSN: 2573-0150

Journal Of Pulmonary Medicine \& Respiratory Research | ISSN: 2573-0177

Journal Of Reproductive Medicine Gynaecology \& Obstetrics | ISSN: 2574-2574

Journal Of Stem Cells Research Development \& Therapy | ISSN: 2381-2060

Journal Of Surgery Current Trends \& Innovations | ISSN: 2578-7284

Journal Of Toxicology Current Research | ISSN: 2639-3735

Journal Of Translational Science And Research

Journal Of Vaccines Research \& Vaccination | ISSN: 2573-0193

Journal Of Virology \& Antivirals

Sports Medicine And Injury Care Journal | ISSN: 2689-8829

Trends In Anatomy \& Physiology | ISSN: 2640-7752

Submit Your Manuscript: https://www.heraldopenaccess.us/submit-manuscript 